\title{
Plums: Calendar of Operations for Home Gardeners
}

\author{
Pamela M. Geisel is UC Cooperative Extension Farm Advisor in Environmental Horticulture for \\ Fresno County; Carolyn L. Unruh is UCCE staff writer for Fresno County; and Paul Vossen is \\ UCCE Farm Advisor in Fruits, Vegetables, and Marketing for Sonoma and Marin Counties.
}

Plum and prune trees can grow in almost all climate zones of California. There are European plums, Japanese varieties, prunes, and cherry-plum or apricotplum interspecific hybrids. Many varieties require a compatible pollenizer to ensure a good fruit set. Be sure to determine this before you plant, since the pollenizer variety will need to grow in close proximity or be grafted into a branch of the tree you select. Most plums tend to overbear, so you have to thin the fruit at the appropriate time in the growing season to produce quality fruit and minimize limb breakage.

\section{Winter Dormant Season}

- If San Jose scale, mites, or aphids have been problems in previous growing seasons, spray the tree with dormant oil late in the dormant season, just prior to bud break. Oil sprays applied late in the dormant season are least likely to cause shoot injury. Be sure to provide thorough coverage of the tree, including the trunk.

- On mature trees, prune out any dead, diseased, or broken branches. Thin branches out (usually 20 percent of last year's growth) to allow good light penetration into the tree. The purpose of thinning cuts is to reduce crop load and increase light penetration. Do not make heading cuts that shorten the tips of the shoots.

\section{Spring Bloom Season}

- Begin to fertilize large, mature trees when they start to push foliage out in the spring. Use a highnitrogen fertilizer such as ammonium sulfate at 3 to 4 pounds per tree per year. Use lower rates for very vigorous trees. Divide the total amount of fertilizer into two portions to be applied in spring and fall (April and early August).

- Thin the fruit to about 4 to 6 inches apart when they are $1 / 2$ to $3 / 4$ inch in diameter. If you want to produce larger mature fruit, leave even fewer immature fruit on the tree.

- Plum aphids often cause curling of the young leaves in spring, but you only need to control them when 50 percent of the leaves are curled and live aphids are present. Insecticides generally are not required during the growing season. If aphid populations become intolerable, however, control them with insecticidal soap, summer weight oil, or malathion.

- To prevent sunburn injury and to reduce borer infestations in very hot regions, paint the trunks and lower branches of young trees with a 1:1 mixture of white interior latex paint and water. Apply the paint mixture from 2 inches below the soil line to 2 feet above. This generally is not a problem if trees receive adequate irrigation during the growing season.

\section{Summer Growing Season}

- If you use drip irrigation, apply just the amount of water needed to replace what is used by the tree and lost from the soil through evaporation. If you use sprinkler or flood irrigation, water about every two to three weeks and provide enough water to wet the soil to a depth of 18 to 24 inches. Water requirements will vary depending on environmental conditions and your soil type.

- Fertilize young or newly planted fruit trees monthly to encourage good strong growth. Use a total of a $1 / 2$ to 1 pound of ammonium sulfate per tree during the growing season, dividing it into three equal applications.

- In late June or early July, remove the strong, vigorous shoots from the interior portion of the canopy to improve light penetration and air circulation in the tree's interior.

- Harvest the fruit when it is firm ripe. Fruit of early varieties may need to be harvested over a period of weeks, while that of later varieties can usually be harvested all at once. Store the harvested fruit under refrigeration to maintain optimum quality. Plums may also be sun-dried, canned, or frozen for longer storage.
Autumn
- Fertilize and irrigate trees just after harvest. Apply 1 to 2 pounds of urea, 3 to 5 pounds of ammonium sulfate, or 20 to 40 pounds of manure per mature tree. Water well after fertilizer application. 


\section{For More Information}

Cousult these UC IPM Pest Notes online at

http:/ / www.ipm.ucdavis.edu:

Aphids

Bordeaux Mixture

Leaf Curl

Scales

Spider Mites

Thrips

You'll also find detailed information on many aspects of fruit and nut tree care in these titles and in other publications, slides sets, and videos from UC ANR:

California Master Gardener Handbook, publication 3382

Drip Irrigation in the Home Landscape, publication 21579

Pests of the Garden and Small Farm, publication 3332

Pruning Fruit and Nut Trees, publication 21171

Sweet Cherries for the Home Grounds, publication 2951

The UC Guide to Solving Garden and Landscape Problems, CD-ROM 3400

\section{ORDERING}

To order these products, visit our online catalog at http: / / anrcatalog.ucdavis.edu. You can also place orders by mail, phone, or fax, or request a printed cata$\log$ of publications, slide sets, and videos from

University of California

Agriculture and Natural Resources

Communication Services

6701 San Pablo Avenue, 2nd Floor

Oakland, California 94608-1239

Telephone: (800) 994-8849 or (510) 642-2431

FAX: (510) 643-5470

E-mail inquiries: danrcs@ucdavis.edu

For a free catalog of other publications, telephone (800) 994-8849.

Visit the ANR Communication Services website at http:/ / anrcatalog.ucdavis.edu.

Publication 7262

(C) 2002 by the Regents of the University of California, Division of Agriculture and Natural Resources. All rights reserved.

The University of California prohibits discrimination against or harassment of any person employed by or seeking employment with the University on the basis of race, color, national origin, religion, sex, physical or mental disability, medical condition (cancer-related or genetic characteristics), ancestry, marital status, age, sexual orientation, citizenship, or status as a covered veteran (special disabled veteran, Vietnam-era veteran or any other veteran who served on active duty during a war or in a campaign or expedition for which a campaign badge has been authorized).

University Policy is intended to be consistent with the provisions of applicable State and Federal laws. Inquiries regarding the University's nondiscrimination policies may be directed to the Affirmative Action/Staff Personnel Services Director, University of California, Agriculture and Natural Resources, 300 Lakeside Drive, 6thFloor, Oakland, CA 94612-3550; 510-987-0096. For information on how to obtain this publication and other ANR CS products, call 800-994-8849.

This publication has been anonymously peer reviewed for technical accuracy by University of California scientists and other qualified professionals. This review process was managed by the ANR Associate Editor for Pomology, Viticulture, and Subtropical Horticulture. 
WARNING ON THE USE OF CHEMICALS

Pesticides are poisonous. Always read and carefully follow all precautions and safety recommendations given on the container label. Store all chemicals in their original labeled containers in a locked cabinet or shed, away from foods or feeds, and out of the reach of children, unauthorized persons, pets, and livestock.

Confine pesticides to the property being treated. Avoid drift onto neighboring properties or gardens containing fruits and/or vegetables ready to be picked.

Dispose of empty containers carefully. Follow label instructions for disposal. Never reuse the containers. Make sure empty containers are not accessible to children or animals. Never dispose of containers where they may contaminate water supplies or natural waterways. Do not pour down sink or toilet. Consult your county agricultural commissioner for correct ways of disposing of excess pesticides. Never burn pesticide containers.

PHYTOTOXICITY: Certain chemicals may cause plant injury if used at the wrong stage of plant development or when temperatures are too high. Injury may also result from excessive amounts or the wrong formulation or from mixing incompatible materials. Inert ingredients, such as wetters, spreaders, emulsifiers, diluents, and solvents, can cause plant injury. Since formulations are often changed by manufacturers, it is possible that plant injury may occur, even though no injury was noted in previous seasons.

Funding for this publication was made possible through a grant from the Elvenia J. Slosson Fund. 